\title{
SINERGISME CENDAWAN ENTOMOPATOGEN LECANICILLIUM LECANII DENGAN INSEKTISIDA NABATI UNTUK MENINGKATKAN EFIKASI PENGENDALIAN TELUR KEPIK COKLAT RIPTORTUS LINEARIS PADA KEDELAI
}

\author{
Yusmani Prayogo \\ Balai Penelitian Tanaman Kacang-kacangan dan Umbi-umbian, Malang \\ Jln. Raya Kendalpayak KM 8, PO.BOX 66 Malang, 65101 \\ Email: manik_galek@yahoo.com
}

\begin{abstract}
Sinergism of entomopathogenic fungi (Lecanicillium lecanii) with botanical insecticide to improve the efficacy control of brown stink bug (Riptortus linearis) on soybean. The aim of the research was to study the synergism of entomopathogenic fungi Lecanicillium lecanii with botanical insecticides to control brown stink bug. The research was carried out in the field experiment station (Kendalpayak) of Indonesian Legume and Tuber Crops Research Institute (ILETRI). Randomized block design (RBD) was used, each treatment was repeated three times. The treatments were three types of botanical insecticides i.e; Aglaia odorata leaf powder (ALP), Annona squamosa seed powder (ASP), and Jatropha curcas seed powder (JSP) of 25, 50 and $75 \mathrm{~g} / 1$ respectively were combined with the conidia of $L$. lecanii. The results showed that the addition of botanical insecticides into the media can improve growth and development of the fungus L. lecanii. The higher dose of botanical insecticide in combination with the L. lecanii, the greater efficacy of both agents are in controlling brown stink bug eggs. Synergism of combination of L. lecanii and botanical insecticides were shown from the number of unhatched eggs (above $77 \%$ ) compared with a single application. The fewer number of brown stink bug eggs hatching, caused the limited number of brown stink bug can developed become adult, resulting reduced soybean seeds and pods damaged. The combination of $L$. lecanii and botanical insecticides was able to maintain weight of soybean seed up to $35 \%$ compared to single treatment (control). The combination of L. lecanii and ASP and JSP botanical pesticides were more synergist compared with combination of L. lecanii with ALP. Dose of $50 \mathrm{~g} / \mathrm{l}$ botanical pesticide JSP and ALP were combined with the L. lecanii was an optimal dose to control of brown stink bug eggs.
\end{abstract}

Key words: botanical insecticide, L. lecanii, egg, R. linearis, soybean

\begin{abstract}
ABSTRAK
Sinergisme cendawan entomopatogen Lecanicillium lecanii dengan insektisida nabati untuk meningkatkan efikasi pengendalian telur kepik coklat Riptortus linearis pada kedelai. Penelitian ini bertujuan untuk mempelajari sinergisme kombinasi cendawan entomopatogen Lecanicillium lecanii dengan insektisida nabati dalam meningkatkan efikasi pengendalian telur kepik coklat. Penelitian dilakukan di kebun percobaan (KP) Kendalpayak (Malang), Balai Penelitian Tanaman Kacangkacangan dan Umbi-umbian pada bulan Maret hingga Juni 2010. Percobaan menggunakan rancangan acak kelompok (RAK), masing-masing perlakuan diulang tiga kali. Perlakuan adalah tiga jenis insektisida nabati yaitu: serbuk daun pacar cina Aglaia odorata (SDA), serbuk biji srikaya Annona squamosa (SBS), dan serbuk biji jarak Jatropha curcas (SBJ) dengan dosis 25,50 dan 75 g/l yang masing-masing dikombinasikan dengan suspensi konidia L. lecanii. Hasil penelitian menunjukkan bahwa penambahan insektisida nabati ke dalam media tumbuh bersifat sinergis karena mampu meningkatkan pertumbuhan dan perkembangan cendawan L. lecanii. Sinergisme kombinasi cendawan L. lecanii dengan insektisida nabati juga ditunjukkan dari jumlah telur kepik coklat yang tidak menetas hingga di atas 77\% dibandingkan dengan aplikasi secara tunggal. Semakin sedikit jumlah telur kepik coklat yang menetas, semakin terbatas jumlah imago yang hidup sehingga peluang biji dan polong kedelai yang rusak juga semakin rendah. Kombinasi cendawan L. lecanii dengan insektisida nabati mampu mempertahankan berat biji kedelai hingga mencapai 35\% dibandingkan tanpa kombinasi (kontrol). Kombinasi cendawan L. lecanii dengan SBJ maupun SBS lebih baik dibandingkan kombinasi L. lecanii dengan SDA. Dosis $50 \mathrm{~g} / 1$ pestisida nabati SBS dan SBJ yang dikombinasikan dengan cendawan L. lecanii merupakan dosis optimal untuk meningkatkan efikasi pengendalian telur kepik coklat.
\end{abstract}

Kata kunci: Insektisida nabati, L. lecanii, telur, R. linearis, kedelai 


\section{PENDAHULUAN}

Kepik coklat Riptortus linearis (F.) (Hemiptera: Alydidae) merupakan salah satu jenis hama pengisap polong kedelai yang sangat penting karena dapat menyebabkan kehilangan hasil hingga mencapai $80 \%$. Pengendalian kepik coklat yang dilakukan petani hingga saat ini hanya mengandalkan keampuhan insektisida kimia. Lebih dari $90 \%$ petani, dalam aplikasi insektisida kimia di lapangan menggunakan dosis dan volume semprot yang tidak sesuai dengan anjuran. Meskipun petani sudah berusaha meningkatkan dosis maupun frekuensi aplikasi, namun populasi kepik coklat di lapangan masih menjadi kendala utama. Hal ini dapat disebabkan hampir semua senyawa insektisida yang dianjurkan belum ada yang mampu menggagalkan penetasan telur (ovisidal). Insektisida kimia hanya mampu membunuh stadia nimfa maupun imago sehingga populasi menjadi tumpang tindih dan pengendalian menjadi kurang berhasil. Hasil penelitian Prayogo (2004 \& 2009a) menunjukkan bahwa cendawan entomopatogen Lecanicillium lecanii mampu bersifat ovisidal terhadap telur kepik coklat. Telur yang terinfeksi L. lecanii akhirnya tidak menetas, meskipun telur mampu menetas tetapi nimfa yang terbentuk tidak mampu hidup berkembang lebih lanjut. Hasil penelitian Prayogo (2004) menunjukkan bahwa aplikasi cendawan L. lecanii secara tunggal hanya mampu menggagalkan penetasan telur kepik coklat sebesar $50 \%$. Salah satu cara untuk meningkatkan efikasi cendawan entomopatogen dalam pengendalian hama, yaitu mengkombinasikan dengan teknologi pengendalian yang lain dengan harapan terjadi efek sinergisme. Menurut Purwar \& Sachan (2006), kombinasi beberapa agens pengendalian dengan tujuan untuk memperoleh sinergisme agar efikasi pengendalian lebih meningkat sangat dianjurkan. Hasil penelitian Feng et al. (2004) menunjukkan bahwa kombinasi antara cendawan entomopatogen Beauveria bassiana atau Paecilomyes fumosoroseus dengan insektisida kimia berbahan aktif imidakloprid bersifat sinergisme karena mampu meningkatkan efikasi pengendalian terhadap Trialeurodes vaporariorum (Hemiptera: Aleyrodidae) dibandingkan dengan aplikasi secara tunggal.

Uji pendahuluan yang dilakukan Prayogo (2009b) menunjukkan bahwa kombinasi antara cendawan $L$. lecanii dengan insektisida nabati serbuk biji srikaya (Annona squamosa) SBS, serbuk biji jarak (Jatropha curcas L.) SBJ, dan daun pacar cina (Aglaia odorata) SDA bersifat sinergis karena mampu meningkatkan pertumbuhan diameter koloni $L$. lecanii secara in vitro dibandingkan dengan kombinasi beberapa jenis insektisida lain. Selain itu, penambahan insektisida nabati ke dalam media tumbuh potato dextrose agar (PDA) dapat meningkatkan jumlah konidia $L$. lecanii yang terbentuk dan jumlah konidia yang berkecambah setelah konidia diinkubasi di dalam air. Peningkatan jumlah konidia dan meningkatnya daya kecambah konidia cendawan L. lecanii mengakibatkan jumlah telur kepik coklat yang tidak menetas semakin banyak (Prayogo, 2009a). Hal ini disebabkan semakin banyak jumlah konidia yang berkecambah, semakin banyak konidia yang berpeluang menginfeksi inang (Cliquet \& Jackson 2005). Penelitian ini bertujuan untuk mempelajari kombinasi dosis tiga jenis insektisida nabati dengan cendawan $L$. lecanii dalam meningkatkan efikasi pengendalian telur kepik coklat.

\section{METODE PENELITIAN}

Tempat dan Waktu. Penelitian dilakukan di laboratorium Entomologi dan kebun percobaan (KP) Balai Penelitian Tanaman Kacang-kacangan dan Umbiumbian (Balitkabi), Malang yang dimulai dari bulan Maret hingga September 2010. Penelitian menggunakan rancangan acak kelompok, masing-masing perlakuan diulang tiga kali. Perlakuan adalah kombinasi suspensi konidia cendawan entomopatogen $L$. lecanii dengan tiga jenis insektisida nabati yaitu serbuk daun pacar cina (Aglaia odorata) SDA, serbuk biji srikaya (Annona squamosa) SBS, dan serbuk biji jarak (Jatropha curcas) SBJ dengan dosis masing-masing $25 \mathrm{~g} / 1,50 \mathrm{~g} / \mathrm{l}$, dan 75 g/l. Ketiga jenis insektisida nabati yang digunakan sebagai perlakuan adalah insektisida nabati yang kompatibel dengan cendawan $L$. lecanii hasil seleksi pada tahun 2010. Penelitian ini dilakukan dua tahap, yaitu uji in vitro dan penelitian semi lapangan.

Uji in vitro. Tiga jenis insektisida nabati (SDA, SBJ dan SBS) yang sudah dibuat menjadi serbuk kemudian ditimbang sesuai dengan dosis perlakuan dan ditambahkan ke dalam media potato dextrose agar (PDA) sebelum disetrilisasi di dalam autoclave. Media tumbuh dituang ke dalam cawan Petri, masing-masing cawan diisi media sebanyak $10 \mathrm{ml}$ kemudian dibiarkan hingga dingin. Cendawan $L$. lecanii yang digunakan adalah isolat Ll-JTM11 (koleksi laboratorium Entomologi Balitkabi) yang memiliki virulensi tinggi dalam menggagalkan penetasan telur kepik coklat (Prayogo, 2009a). Isolat cendawan dikulturkan pada media PDA, pada umur 14 hari biakan cendawan tersebut dilubangi menggunakan bor yang berdiamater satu $\mathrm{cm}$ selanjutnya inokulum cendawan diinokulasikan pada masing-masing 
media PDA yang sudah mengandung insektisida nabati sebagai perlakuan di dalam cawan Petri. Variabel yang diamati adalah; (1) diameter koloni cendawan yang diukur setiap 24 jam setelah inokulasi, (2) jumlah konidia yang terbentuk pada setiap $1 \mathrm{~g}$ biakan cendawan yang diencerkan dengan air $100 \mathrm{ml}$ yang dilakukan pada umur 21 hari setelah inokulasi, dan (3) jumlah konidia $L$. lecanii yang berkecambah setelah diinkubasi di dalam air selama 12 jam (Prayogo, 2009a).

Penelitian Semi Lapangan. Kedelai varietas Wilis ditanam di lahan dengan jarak tanam $40 \mathrm{~cm}$ x $15 \mathrm{~cm}$, setiap lubang diisi dua biji. Tanaman dipelihara (pemupukan, penyiangan dan pengairan) sesuai dengan rekomendasi bertanam kedelai. Untuk mempertahankan tanaman dalam kondisi yang optimal maka tanaman disemprot dengan pestisida kimia efektif sesuai dengan hama maupun patogen yang ada. Penggunaan pestisida kimia dihentikan satu minggu sebelum perlakuan aplikasi kombinasi cendawan $L$. lecanii dengan insektisida nabati dilakukan dengan tujuan agar kinerja dari agens hayati tersebut optimal dan tidak dipengaruhi oleh penggunaan pestisida kimia. Pada umur 35 hari setelah tanam, setiap tanaman yang digunakan sebagai contoh diinfestasi dengan telur kepik coklat yang berumur satu hari setelah diletakkan imago. Setiap tanaman contoh diinfestasi sebanyak 100 butir telur yang ditempelkan pada bagian permukaan daun bagian atas menggunakan lem gom arab. Selanjutnya, tanaman dikurung menggunakan kain kasa halus yang tembus sinar matahari dengan tujuan aktivitas sinar matahari tidak dipengaruhi oleh kain kasa sebagai penutup tanaman.

Cendawan L. lecanii isolat L1-JTM11 ditumbuhkan pada media potato dextrose agar (PDA) di dalam cawan Petri yang berdiameter $9 \mathrm{~cm}$. Pada umur 21 hari setelah inokulasi (HSI), kumpulan konidia yang terbentuk diambil dengan cara dikerok menggunakan kuas halus kemudian dimasukkan ke dalam erlenmeyer yang berisi air steril. Suspensi konidia yang sudah terkumpul dihitung menggunakan haemocytometer hingga memproleh kerapatan konidia $10^{8} / \mathrm{mL}$ kemudian dibagi ke dalam beberapa erlenmeyer yang jumlahnya sesuai dengan perlakuan.

Masing-masing jenis bahan insektisida nabati sebagai perlakuan dikeringkan dengan sinar matahari kemudian ditumbuk hingga halus membentuk tepung. Setiap jenis insektisida nabati ditimbang sesuai dengan perlakuan kemudian dimasukkan ke dalam masingmasing erlenmeyer yang sudah berisi suspensi konidia L. lecanii. Erlenmeyer yang berisi suspensi konidia dikocok menggunakan shaker selama 30 menit sebelum suspensi konidia disemprotkan pada kelompok telur kepik coklat. Aplikasi dilakukan pada sore hari pukul 16:00 WIB untuk menghindari pengaruh negatif dari sinar matahari. Variabel yang diamati adalah: (1) jumlah telur kepik coklat menetas, (2) waktu penetasan telur kepik coklat setelah diaplikasi, (3) jumlah polong hampa, (4) jumlah polong isi, (5) jumlah luka tusukan pada tiap biji kedelai akibat stilet kepik coklat, dan (6) berat biji tiap tanaman.

\section{HASIL DAN PEMBAHASAN}

\section{Pengaruh Jenis dan Dosis Insektisida Nabati pada Media Tumbuh terhadap Diameter Koloni $L$.} lecanii. Uji in-vitro bertujuan untuk mempelajari pengaruh pada media tumbuh yang mengandung insektisida nabati SDA, SBJ dan SBS dengan dosis 25, 50 dan $75 \mathrm{~g} / 1$ terhadap pertumbuhan dan perkembangan cendawan entomopatogen $L$. lecanii. Hasil penelitian menunjukkan bahwa dosis dan jenis insektisida nabati yang ditambahkan pada media tumbuh berpengaruh nyata terhadap diameter koloni $L$. lecanii mulai tiga sampai dengan 21 hari setelah inokulasi (HSI). Pada tiga HSI, tampak diameter koloni terlebar terjadi pada perlakuan SBJ $50 \mathrm{~g} / 1$ yaitu sebesar 12,89 mm (Tabel 1). Diameter koloni terendah terjadi pada perlakuan kontrol (media PDA), yaitu hanya $10,10 \mathrm{~mm}$.

Pada enam HSI, diameter koloni $L$. lecanii yang terlebar terjadi pada perlakuan insektisida nabati SBJ, baik dosis terendah $25 \mathrm{~g} / \mathrm{l}$ hingga dosis $75 \mathrm{~g} / \mathrm{l}$ yaitu berkisar dari 18,30-18,51 mm. Diameter koloni terendah terjadi pada kontrol (tanpa insektisida nabati) yaitu hanya $16,63 \mathrm{~mm}$, meskipun tidak berbeda nyata terhadap perlakuan insektisida nabati SDA dan SBS pada semua dosis yang diuji. Pada sembilan HSA, diameter koloni L. lecanii tidak berbeda nyata diantara perlakuan jenis dan dosis insektisida nabati, namun berbeda nyata terhadap kontrol (tanpa insektisida nabati). Rerata diameter koloni mengalami penambahan sesuai dengan bertambahnya waktu pengamatan meskipun penambahannya tidak terlalu mencolok, namun dengan penambahan insektisida nabati kedalam media tumbuh berpengaruh nyata terhadap diameter koloni cendawan.

Hingga $21 \mathrm{HSI}$, penambahan insektisida nabati mampu meningkatkan diameter koloni L. lecanii sehingga mencapai 43,90 mm. Diameter koloni cendawan pada umur tersebut tidak berbeda nyata diantara jenis maupun dosis insektisida nabati yang diuji, namun perlakuan insektisida nabati berbeda nyata dibandingkan dengan kontrol yang hanya $42 \mathrm{~mm}$. Diameter terlebar diperoleh dari perlakuan SBJ pada 
Tabel 1. Diameter koloni L. lecanii yang ditumbuhkan pada media yang mengandung insektisida nab ati SDA, SBS, dan SBJ

\begin{tabular}{lccccccc}
\hline \multirow{2}{*}{ Perlakuan } & \multicolumn{7}{c}{ Diameter koloni L. lecanii $(\mathrm{mm}) \mathrm{HSI}$} \\
\cline { 2 - 8 } & 3 & 6 & 9 & 12 & 15 & 18 & 21 \\
\hline SDA 25 g/1 & $10,20 \mathrm{c}$ & $16,33 \mathrm{bc}$ & $21,33 \mathrm{ab}$ & $27,00 \mathrm{~b}$ & $31,33 \mathrm{a}$ & $36,33 \mathrm{ab}$ & $43,00 \mathrm{a}$ \\
SD A 50 g/l & $10,20 \mathrm{c}$ & $16,29 \mathrm{bc}$ & $20,99 \mathrm{ab}$ & $27,10 \mathrm{~b}$ & $31,63 \mathrm{a}$ & $36,49 \mathrm{ab}$ & $43,15 \mathrm{a}$ \\
SDA 75 g/1 & $10,25 \mathrm{c}$ & $16,36 \mathrm{bc}$ & $20,85 \mathrm{ab}$ & $27,15 \mathrm{~b}$ & $31,60 \mathrm{a}$ & $36,00 \mathrm{ab}$ & $43,45 \mathrm{a}$ \\
SBS 25 g/l & $11,67 \mathrm{~b}$ & $16,53 \mathrm{~b}$ & $21,67 \mathrm{a}$ & $27,50 \mathrm{~b}$ & $31,67 \mathrm{a}$ & $36,67 \mathrm{ab}$ & $43,47 \mathrm{a}$ \\
SBS 50 g/l & $12,75 \mathrm{a}$ & $16,33 \mathrm{bc}$ & $21,90 \mathrm{a}$ & $27,45 \mathrm{~b}$ & $31,99 \mathrm{a}$ & $37,17 \mathrm{a}$ & $43,50 \mathrm{a}$ \\
SBS 75 g/l & $12,18 \mathrm{a}$ & $16,70 \mathrm{c}$ & $21,75 \mathrm{a}$ & $27,50 \mathrm{~b}$ & $31,87 \mathrm{a}$ & $37,30 \mathrm{a}$ & $43,48 \mathrm{a}$ \\
SBJ 25 g/l & $12,67 \mathrm{a}$ & $18,47 \mathrm{a}$ & $21,67 \mathrm{a}$ & $28,67 \mathrm{a}$ & $32,67 \mathrm{a}$ & $37,15 \mathrm{a}$ & $43,50 \mathrm{a}$ \\
SBJ 50 g/l & $12,89 \mathrm{a}$ & $18,51 \mathrm{a}$ & $22,75 \mathrm{a}$ & $28,70 \mathrm{a}$ & $32,33 \mathrm{a}$ & $37,27 \mathrm{a}$ & $43,78 \mathrm{a}$ \\
SBJ 75 g/l & $12,62 \mathrm{a}$ & $18,30 \mathrm{a}$ & $22,17 \mathrm{a}$ & $28,00 \mathrm{a}$ & $32,40 \mathrm{a}$ & $37,38 \mathrm{a}$ & $43,90 \mathrm{a}$ \\
Kontrol & $10,10 \mathrm{c}$ & $16,63 \mathrm{c}$ & $20,20 \mathrm{~b}$ & $26,00 \mathrm{c}$ & $30,55 \mathrm{~b}$ & $35,25 \mathrm{~b}$ & $42,00 \mathrm{~b}$ \\
\hline
\end{tabular}

* HSI (hari setelah inokulasi). Angka sekolom yang diikuti oleh huruf yang sama menu njukkan tidak berbed a nyata pada uji Duncan ( $p>0,05)$.

semua dosis yang diuji yaitu berkisar 43,50-43,90 mm. Perlakuan SBS juga menunjukkan penambahan diameter yang lebih lebar dibandingkan dengan perlakuan SDA meskipun tidak berbeda nyata. Ditinjau dari diameter koloni maka kedua perlakuan, yaitu SBS dan SBJ lebih baik dibandingkan dengan SDA. Diduga karena kandungan minyak dari ekstrak biji SBS dan SBJ lebih tinggi maka akan memperkaya nutrisi media tumbuh sehingga kualitas media tersebut lebih baik dibandingkan dengan insektisida nabati dari serbuk daun Aglaia odorata. Biji Srikaya dan biji jarak mengandung senyawa minyak berkisar dari 41-66\% lebih tinggi dibandingkan dengan serbuk daun Aglaia yaitu hanya 0,6-3,2\% (Greger et al., 2001; Adebowale \& Adedire, 2006; Kimbonguila et al., 2010). Minyak terdiri dari komponen asam lemak jenuh dan asam lemak tidak jenuh.

Asam lemak khususnya yang tidak jenuh merupakan sumber nutrisi yang baik dan mudah terhidrolisis (Luthana, 2008), terutama sumber nitrogen bagi pertumbuhan mikrob termasuk cendawan. Tahapan perombakan ini dimulai dengan dekomposisi gliserida menjadi gliserol dan asam lemak. Perombakan gliserol dapat menghasilkan lebih dari 20 macam senyawa yang termasuk golongan aldehida, asam organik, dan senyawa lainnya (Ketaren, 2005). Gliserol maupun asam lemak merupakan sumber energi yang baik bagi mikrob untuk pertumbuhan maupun perkembangan cendawan.

\section{Pengaruh Jenis dan Dosis Insektisida Nabati pada} Media Biakan terhadap Jumlah Konidia Cendawan L. lecanii yang Terbentuk. Hasil penelitian menunjukkan bahwa jenis dan dosis insektisida nabati yang ditambahkan di dalam media tumbuh berpengaruh nyata terhadap pembentukan konidia L. lecanii. Penambahan insektisida nabati SBJ menghasilkan konidia dalam jumlah yang lebih banyak dibandingkan dengan insektisida SBS maupun SDA. Jumlah konidia L. lecanii terbanyak pada perlakuan SBJ $75 \mathrm{~g} / \mathrm{l}$ yaitu hingga mencapai 9,89 x 103/ml (Tabel 2). Semakin tinggi dosis SBJ yang ditambahkan ke dalam media tumbuh, semakin banyak jumlah konidia yang terbentuk. Meskipun pestisida SBS yang ditambahkan ke media tumbuh meningkatkan jumlah konidia yang dihasilkan namun hanya dosis $50 \mathrm{~g} / \mathrm{l}$ yang tampak peningkatan tertinggi dibandingkan dosis 25 maupun $75 \mathrm{~g} / \mathrm{l}$. Dengan demikian, dosis insektisida SBS yang sesuai untuk dikombinasikan dengan $L$. lecanii adalah $50 \mathrm{~g} / \mathrm{L}$. Sedangkan peningkatan dosis insektisida nabati SDA, tidak tampak adanya peningkatan jumlah konidia yang sangat signifikan karena jumlah konidia yang terbentuk hampir sama dengan perlakuan kontrol (tanpa insektisida nabati). Hal ini diduga berhubungan dengan perbedaan kandungan senyawa kimia dari masing-masing jenis insektisida nabati. Pada perlakuan SBS dan SBJ merupakan biji yang dibuat menjadi serbuk halus sehingga memiliki kandungan nutrisi yang sangat tinggi dibandingkan dengan SDA, yaitu serbuk daun.

Biji memiliki kandungan karbohidrat maupun protein yang lebih tinggi sehingga nutrisi tersebut cukup berperan dalam proses pertumbuhan maupun perkembangan cendawan termasuk pembentukan konidia. Kimbonguila et al. (2010) melaporkan bahwa biji srikaya mengandung karbohidrat sebanyak $34,10 \%$ dan protein sebesar $9,70 \%$. Sementara itu, pada biji jarak mengandung karbohidrat $30,11 \%$ dan protein berkisar dari 13,40-32,88\% (Oladele \& Oshodi, 2007; Abou-Arab 
Tabel 2. Jumlah konidia L. lecanii yang terbentuk pada media tumbuh yang mengandung insektisida nabati SBS, SJB dan SDA serta konidia yang berkecambah setelah diinkubasi selama 10 jam di dalam air

\begin{tabular}{ccc}
\hline $\begin{array}{c}\text { Dosis dan jenis insektisida } \\
\text { nabati }\end{array}$ & $\begin{array}{c}\text { Konidia L. lecanii } \\
(\times 10 \%)\end{array}$ & $\begin{array}{c}\text { Konidia L. lecanii } \\
\text { berkecambah }(\%)\end{array}$ \\
\hline SDA 25 g/l & 6,368 & 90,75 \\
SDA 50 g/l & 6,470 & 90,80 \\
SDA 75 g/l & 6,450 & 90,78 \\
SBS 25 g/l & 7,658 & 92,35 \\
SBS 50 g/l & 8,755 & 92,40 \\
SBS 75 g/l & 7,650 & 92,35 \\
SB J 25 g/1 & 9,728 & 93,40 \\
SB J 50 g/1 & 9,878 & 93,56 \\
SB J 75 g/1 & 9,890 & 92,78 \\
Kontrol (PDA) & 6,350 & 86,14 \\
\hline
\end{tabular}

\& Abu-Salem, 2010). Kandungan protein yang terdapat pada tiap biji srikaya tidak sama tergantung dari metode prosesing yang digunakan (Chivandi et al., 2005; Magdi, 2007; Makkar et al., 2008). Menurut Gao et al. (2007) dan Nehls (2008) karbohidrat merupakan sumber nutrisi utama bagi pembentukan konidia cendawan.

Penambahan insektisida nabati selain meningkatkan jumlah konidia yang terbentuk juga berkorelasi positif terhadap daya kecambah konidia (Tabel 2). Semua jenis insektisida nabati yang ditambahkan ke dalam PDA sebagai media tumbuh bagi L. lecanii berpengaruh positif terhadap kemampuan perkecambahan konidia yang sudah terbentuk. Media yang mengandung insektisida nabati SDA, SBS, maupun SBJ lebih unggul dalam memicu peningkatan jumlah konidia yang berkecambah, hal ini tampak jelas jika dibandingkan dengan persentase perkecambahan pada perlakuan kontrol. Jumlah konidia yang mampu berkecambah terbanyak hingga mencapai $93,56 \%$ yaitu terjadi pada perlakuan SBJ dengan dosis $50 \mathrm{~g} / \mathrm{l}$. Jumlah konidia yang berkecambah terbanyak diikuti oleh SBJ dosis $25 \mathrm{~g} / \mathrm{l}$ dan jika dosis SBJ ditingkatkan menjadi 75 $\mathrm{g} / \mathrm{l}$ tidak terjadi peningkatan persentase perkecambahan. Akan tetapi perkecambahan semakin berkurang lebih rendah dibandingkan kedua dosis yang diuji. Jumlah konidia yang berkecambah terendah terjadi pada perlakuan SDA pada semua dosis yang diuji, yaitu berkisar 90,75-90,80\%. Meskipun demikian, penambahan insektisida SDA ke dalam media tumbuh masih lebih baik jika dibandingkan dengan tanpa perlakuan (kontrol).

Pada perlakuan penambahan insektisida nabati yang berasal dari biji-bijian, khususnya SBS dan SBJ memiliki peluang untuk berkecambah jauh lebih banyak dibandingkan dengan SDA. Hal ini diduga pada kedua jenis bahan nabati tersebut banyak mengandung lemak, selain karbohidrat maupun protein. Lemak yang terkandung dalam biji terdiri dari asam lemak jenuh dan asam lemak tidak jenuh. Menurut Kim et al. (2010) asam lemak tidak jenuh (linoleat) dapat memicu terjadinya peningkatan perkecambahan konidia. Semakin banyak jumlah konidia yang berkecambah akan semakin besar peluang konidia yang mampu menginfeksi inang (Rangel et al. 2008). Senyawa minyak berperan dalam meningkatkan kelembaban konidia sehingga memicu terjadinya perkecambahan dan akhirnya meningkatkan infeksi konidia pada inang (Ganga-Visalakshy et al., 2005; Su et al., 2010). Dengan demikian, senyawa minyak cukup berperan dalam peningkatan efikasi cendawan entomopatogen dalam pengendalian hama. Oleh karena itu, untuk meningkatkan efikasi pengendalian hama menggunakan agens hayati cendawan entomopatogen disarankan menambahkan minyak nabati sebelum aplikasi di lapangan (Inyang et al., 2000; Bandani \& Esmailpaur, 2006; Safavi et al., 2007).

Pengaruh Aplikasi Kombinasi Insektisida Nabati dan Cendawan L. lecanii terhadap Penetasan Telur Kepik Coklat. Aplikasi dari kombinasi SDA, SBS, SBJ dengan cendawan entomopatogen L. lecanii berpengaruh nyata terhadap penetasan telur kepik coklat. Pada enam hari setelah aplikasi (HSA), tampak aplikasi insektisida nabati SBS $75 \mathrm{~g} / 1$ yang dikombinasikan dengan L. lecanii tidak ditemukan adanya telur kepik coklat yang menetas (Tabel 3). Jumlah telur kepik coklat yang menetas terbanyak terjadi pada perlakuan aplikasi kombinasi SDA $25 \mathrm{~g} / \mathrm{l}$ dengan 
Tabel 3. Jumlah telur kepik coklat yang menetas setelah diaplikasi mengggun akan kombinasi insektisida nabati dan cendaw an L. lecanii

\begin{tabular}{cccc}
\hline \multirow{2}{*}{ Perlakuan $(\mathrm{g} / \mathrm{l})$} & \multicolumn{3}{c}{ Jumlah telur kepik coklat menetas pada umur (HSA) } \\
\cline { 2 - 4 } & 6 & 9 & 11 \\
\hline SD A 25 g/l & $22,90 \mathrm{~b}$ & $24,13 \mathrm{~b}$ & $39,43 \mathrm{~b}$ \\
SD A 50 g/l & $10,97 \mathrm{bc}$ & $26,53 \mathrm{~b}$ & $37,57 \mathrm{~b}$ \\
SD 75 g/l & $3,33 \mathrm{c}$ & $18,47 \mathrm{bc}$ & $26,83 \mathrm{bc}$ \\
SBS 25 g/l & $11,57 \mathrm{bc}$ & $23,33 \mathrm{~b}$ & $40,63 \mathrm{~b}$ \\
SBS 50 g/l & $11,57 \mathrm{bc}$ & $20,10 \mathrm{~b}$ & $22,87 \mathrm{c}$ \\
SBS 75 g/l & $0,00 \mathrm{c}$ & $3,33 \mathrm{c}$ & $35,90 \mathrm{bc}$ \\
SBJ 25 g/l & $14,60 \mathrm{bc}$ & $21,10 \mathrm{~b}$ & $36,20 \mathrm{bc}$ \\
SBJ 50 g/l & $4,76 \mathrm{c}$ & $16,33 \mathrm{bc}$ & $31,93 \mathrm{bc}$ \\
SBJ 75 g/l & $4,76 \mathrm{c}$ & $20,27 \mathrm{~b}$ & $30,50 \mathrm{bc}$ \\
Tanpa pengendalian & $83,20 \mathrm{a}$ & $98,97 \mathrm{a}$ & $98,97 \mathrm{a}$ \\
\hline
\end{tabular}

HSA (hari setelah aplikasi). Angka sekolom yang diikuti oleh huruf yang sama menunjukkan tidak berbed a nyata pada uji Duncan $(p>0,05)$.

L. lecanii yaitu sebanyak 22 butir. Pada perlakuan kontrol (tanpa aplikasi), jumlah telur yang menetas hingga mencapai 80 butir. Pada sembilan HSA, aplikasi SBS $75 \mathrm{~g} / \mathrm{l}$ yang dikombinasikan dengan cendawan $L$. lecanii dinilai cukup efektif dalam menghambat penetasan telur kepik coklat. Pada perlakuan tersebut jumlah telur yang menetas hanya 3 butir dan lebih sedikit dibandingkan dengan perlakuan yang lainnya. Sementara itu, penetasan telur pada perlakuan kontrol hampir mencapai $100 \%$ dari 100 butir yang diuji yang mampu menetas mencapai 98 butir.

Pada pengamatan hari ke 11 menunjukkan bahwa aplikasi kombinasi SBS $50 \mathrm{~g} / \mathrm{l}$ dengan $L$. lecanii dinilai sangat efektif dibandingkan dengan perlakuan yang lain. Hal ini ditunjukkan dari jumlah telur yang menetas hanya sekitar 22 butir berarti jumlah telur yang tidak menetas mencapai $78 \%$. Diduga insektisida nabati yang berasal dari biji-bijian mengandung senyawa minyak yang lebih tinggi dibandingkan dengan insektisida yang berasal dari organ daun. Minyak nabati yang berasal dari biji-bijian banyak mengandung senyawa gliserol yang berfungsi sebagai pelindung bagi konidia dari faktor abiotik, khususnya sinar matahari karena gliserol mampu merefleksikan sinar yang datang. Dengan demikian kelembaban konidia dapat dipertahankan meskipun pada kondisi kurang menguntungkan, sehingga persentase perkecambahan konidia meningkat dan peluang konidia dapat menginfeksi telur juga lebih banyak akhirnya telur yang menetas terbatas.

Menurut Akbar et al. (2009) senyawa minyak yang terkandung di dalam biji jarak yaitu mencapai $63,16 \%$ jauh lebih tinggi dibandingkan dengan minyak yang terkandung dari biji lain. Hasil penelitian lain juga mengindikasikan bahwa biji jarak mengandung senyawa minyak yang lebih tinggi dibandingkan dengan biji wijen, biji kacang-kacangan maupun biji dari tembakau (Gunstone, 2004; Marti'nez-Herrera et al., 2006; Banapurmath et al., 2008; Kumar \& Sharma, 2008). Sementara itu, Proksch et al. (2001) melaporkan bahwa kandungan minyak dari Aglaia spp. hanya di bawah $40 \%$.

Kombinasi insektisida nabati dengan cendawan L. lecanii lebih efektif dalam menekan jumlah telur kepik coklat yang menetas dibandingkan dengan aplikasi $L$. lecanii secara tunggal, yaitu hanya mampu menggagalkan penetasan telur kepik coklat sebanyak 50\% (Prayogo, 2004). Namun demikian, berapapun jumlah telur yang tidak menetas itu bukan satu ukuran yang menjadi fakor pembatas bagi pengembangan kombinasi agens hayati ini sebagai calon bioinsektisida. Hal ini disebabkan agens hayati tersebut memiliki beberapa keunggulan dibandingkan dengan teknologi pengendalian lainnya, khususnya insektisida kimia. Kenyataan tersebut didukung oleh belum ditemukannya insektisida kimia yang benar-benar bersifat ovisidal terhadap telur serangga hama kepik coklat. Selain itu, bioinsektisida tersebut tidak menyebabkan resistensi ke serangga inang dan aman terhadap serangga berguna (predator dan parasitoid) maupun lingkungan (Wang et al., 2007; Sitch \& Jackson, 2008; Fatiha et al., 2008; Koul \& Walla, 2009).

Pada Tabel 3, terlihat bahwa telur kepik coklat yang diaplikasi dengan kombinasi insektisida nabati dengan L. lecanii, waktu penetasan telur menjadi terlambat beberapa hari bahkan hingga lima hari. Pengamatan lebih lanjut pada telur-telur yang tidak 
menetas pada hari ke 11 tampak dikolonisasi oleh miselium L. lecanii pada seluruh permukaan telur sehingga berwarna putih seperti kapas (Gambar 1). Namun tidak semua telur kepik coklat yang tidak menetas ditandai dengan kolonisasi miselium $L$. lecanii secara penuh. Telur kepik coklat yang tidak menetas juga dipengaruhi oleh aktivitas insektisida nabati, selain pengaruh dari infeksi $L$. lecanii. Fenomena ini terjadi pada suspensi insektisida nabati yang melapisi lubang alami telur (mikropil) akan memblokir lubang tersebut sehingga proses fisiologis terganggu. Diduga suspensi insektisida nabati tersebut juga memiliki toksisitas terhadap telur kepik coklat sehingga akhirnya telur tidak dapat menetas. Hasil penelitian lain mengindikasikan bahwa senyawa minyak nabati dari biji jarak mampu menggagalkan penetasan telur hama gudang Callosobruchus maculatus selain besifat sebagai penghambat dalam peletakan telur (Adabie-Gomez et al., 2006; Adebowale \& Adedire, 2006).

\section{Pengaruh Aplikasi Kombinasi Insektisida Nabati dengan Cendawan Entomopatogen L. lecanii terhadap Jumlah Luka pada Biji Kedelai Akibat Stilet Kepik Coklat. Jumlah tusukan pada setiap biji} kedelai yang diakibatkan oleh stilet kepik coklat yang diamati setelah panen digunakan sebagai salah satu indikator untuk menilai tingkat kerusakan pada biji. Biji kedelai yang tertusuk oleh stilet mengalami luka pada bagian struktur kulit dan bagian dalam biji. Biji yang tertusuk hingga pada lapisan yang dalam dapat mengakibatkan kerusakan yang berat sehingga biji akhirnya menjadi hampa. Hasil penelitian menunjukkan bahwa jumlah tusukan terbanyak terjadi pada kontrol (tanpa perlakuan), yaitu hingga mencapai 21,41 luka (Tabel 4). Pada perlakuan kombinasi insektisida nabati dengan L. lecanii, jumlah luka tusukan terbanyak terjadi pada aplikasi kombinasi SBS $75 \mathrm{~g} / \mathrm{l}$ dengan L. lecanii, yaitu sebanyak 13,88 luka. Perlakuan tersebut jumlahnya lebih banyak dan secara statistik berbeda nyata dibandingkan dengan perlakuan kombinasi yang lainnya.

Jumlah luka tusukan pada biji yang terendah terjadi pada perlakuan aplikasi kombinasi insektisida SBJ dengan L. lecanii, yaitu hanya 2,34 luka. Meskipun jumlah luka lebih sedikit pada tiap biji belum dapat dikatakan kalau biji-biji yang dihasilkan pada perlakuan tersebut tingkat kerusakannya juga lebih ringan. Tingkat kedalaman tusukan pada biji juga sangat berpengaruh terhadap kerusakan biji selain jumlah tusukan. Tusukan stilet kepik coklat mencapai daerah endosperm biji, sehingga isi dari biji tersebut juga habis selanjutnya biji menjadi hampa. Begitu juga jumlah tusukan pada biji yang lebih banyak kalau luka tersebut tidak sampai bagian endosperm biji maka biji juga masih selamat dan tidak hampa meskipun terdapat luka berwarna hitam. Jumlah luka yang banyak tersebut dapat terjadi pada biji kedelai yang terserang kepik coklat pada waktu pengisian biji, namun apabila serangan kepik coklat terjadi pada waktu pemasakan biji maka tusukan tidak mengakibatkan kerusakan biji.

Dari hasil penelitian ini, jumlah luka tusukan pada biji kedelai tidak dapat dibuat sebagai satu-satunya tolok ukur dalam mengukur efikasi kombinasi insektisida nabati dengan cendawan $L$. lecanii dalam mengendalikan hama khususnya pengisap polong seperti kepik coklat tanpa didukung oleh parameter yang lainnya. Komponen parameter lain yang dapat digunakan sebagai tolok ukur adalah jumlah polong hampa, jumlah polong isi, berat biji tiap tanaman atau berat biji tiap 100 butir. Hasil penelitian Sumartini et al. (2001) juga tidak mengindikasikan hasil yang nyata apabila jumlah luka tusukan digunakan sebagai salah satu tolok ukur

Tabel 4. Jumlah luka tusukan pada tiap biji, jum lah polong hampa, ju mlah polong isi dan berat biji kering tiap tanaman yang diap likasi ko mbinasi insektisida nabati dengan cendawan L. lecanii

\begin{tabular}{ccccc}
\hline Perlakuan & $\begin{array}{c}\text { Jumlah luka tusukan } \\
\text { pada tiap biji kedelai }\end{array}$ & $\begin{array}{c}\text { Jumlah polong hampa } \\
\text { tiap tanaman (buah) }\end{array}$ & $\begin{array}{c}\text { Jumlah polong isi } \\
\text { tiap tanaman (buah) }\end{array}$ & $\begin{array}{c}\text { Berat biji tiap } \\
\text { tanaman (g) }\end{array}$ \\
\hline SDA 25 g/l & $6,77 \mathrm{~cd}$ & 10 & 34 & $10,13 \mathrm{def}$ \\
SDA 50 g/l & $6,73 \mathrm{~cd}$ & 11 & 33 & $11,13 \mathrm{~cd}$ \\
SDA 75 g/l & $6,20 \mathrm{~cd}$ & 15 & 29 & $10,83 \mathrm{cde}$ \\
SBS 25 g/l & $4,26 \mathrm{~cd}$ & 10 & 34 & $11,77 \mathrm{bc}$ \\
SBS 50 g/1 & $7,76 \mathrm{~cd}$ & 8 & 36 & $13,17 \mathrm{a}$ \\
SBS 75 g/l & $13,88 \mathrm{~b}$ & 15 & 29 & $9,56 \mathrm{ef}$ \\
SBJ 25 g/l & $4,67 \mathrm{~cd}$ & 13 & 31 & $10,80 \mathrm{cde}$ \\
SBJ 50 g/l & $2,34 \mathrm{~d}$ & 11 & 33 & $13,80 \mathrm{ab}$ \\
SBJ 75 g/l & $9,97 \mathrm{bc}$ & 13 & 25 & $9,96 \mathrm{def}$ \\
Kontrol & $21,41 \mathrm{a}$ & 15 & 29 & $9,16 \mathrm{f}$ \\
\hline
\end{tabular}

Angka sekolom yang diikuti oleh huruf yang sama menunjukkan tidak berbeda nyata pada uji Duncan ( $>00,05)$. 


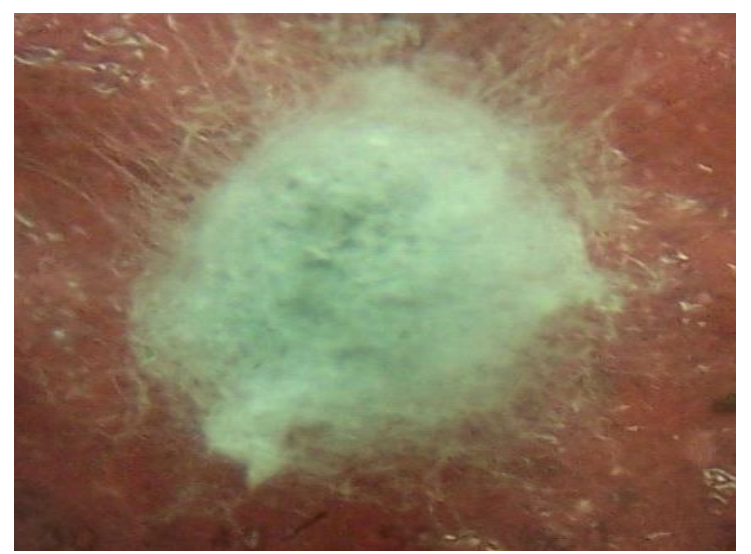

Gambar 1. Telur kepik coklat yang tidak menetas karena terinfeksi dan terkolonisasi miselium cendawan L. lecanii pada umur 11 HSA

kerusakan biji akibat serangan pengisap polong. Hal ini disebabkan jumlah luka tusukan pada biji yang dikendalikan menggunakan cendawan Metarhizium anisopliae juga masih banyak dan hampir sebanding dengan pada perlakuan kontrol (tanpa aplikasi). Perbedaan terletak pada biji yang diberi perlakuan aplikasi ternyata bekas tusukan-tusukan stilet tidak mengakibatkan kerusakan pada biji. Hal ini disebabkan serangga yang sudah sakit akitivitas menusuknya sudah tidak sekuat dibandingkan serangga sehat. Oleh karena di dalam tubuhnya ada patogen maka untuk memenuhi energi, serangga tersebut meningkatkan aktivitasnya yaitu menusuk-nusuk biji namun itu hanya berlangsung sebentar dan tidak mempunyai kekuatan lebih karena serangga sakit. Berbeda dengan pada serangga sehat, meskipun hanya menusuk sekali dan dianggap itu sudah cocok dengan keinginan serangga, maka kegiatan tersebut diteruskan hingga serangga kenyang sehingga isi biji habis meskipun jumlah tusukan hanya sedikit.

Pengaruh Aplikasi Kombinasi Insektisida Nabati dengan Cendawan L. lecanii terhadap Jumlah Polong Hampa. Hasil penelitian menunjukkan bahwa semakin tinggi dosis insektisida nabati yang diaplikasikan dengan cendawan $L$. lecanii, semakin banyak jumlah polong hampa yang ditemukan. Pada ombinasi insektisida SDA $25 \mathrm{~g} / \mathrm{l}$ dengan L. lecanii tampak jumlah polong hampa yang terbentuk lebih sedikit, yaitu hanya 10 buah jika dibandingkan dengan dosis SDA 50 maupun $75 \mathrm{~g} / \mathrm{l}$ yaitu masing-masing 11 dan 15 buah (Tabel 4). Sedangkan pada perlakuan kombinasi insektisida SBS dengan dosis $50 \mathrm{~g} / 1$ dengan L. lecanii memiliki sinergisme yang lebih baik jika dibandingkan dengan dosis 25 maupun $75 \mathrm{~g} / \mathrm{l}$. Hal ini tampak jumlah polong hampa yang terbentuk lebih sedikit yaitu hanya 8 buah, sementara itu pada dosis 50 dan $75 \mathrm{~g} / \mathrm{l}$ masing-masing
10 dan 15 buah. Perlakuan kombinasi insektisida SBJ dengan $L$. lecanii juga sama pola jumlah polong hampa yang terjadi dengan perlakuan kombinasi SDA dengan L. lecanii, yaitu semakin tinggi dosis insektisida yang diaplikasikan juga semakin banyak jumlah polong hampa yang terbentuk. Dilihat dari jumlah polong hampa yang terbentuk maka kombinasi perlakuan insektisida SBS $50 \mathrm{~g} / 1$ dengan L. lecanii tampak lebih sinergis dibandingkan dengan perlakuan lainnya karena jumlah polong hampa hanya 8 buah. Sedangkan jumlah polong hampa terbanyak hingga 15 buah terjadi pada perlakuan kombinasi insektisida nabati dosis tertinggi ( $75 \mathrm{~g} / \mathrm{l}$, SDA dan SBS) dengan L. lecanii.

Hasil penelitian ini mengindikasikan bahwa jumlah polong hampa tidak dapat digunakan sebagai satu tolok ukur efikasi pengendalian yang digunakan. Hal ini disebabkan jumlah polong hampa yang terjadi adalah bukan dari akibat serangan kepik coklat apabila ditinjau dari keadaan polong. Indikasi polong hampa yang disebabkan oleh kepik coklat adalah adanya bekas luka tusukan oleh stilet yang berwarna hitam pada permukaan polong. Hasil pengamatan dengan menggunakan mikroskop stereo menunjukkan bahwa hampir 50\% akibat kondisi musim hujan. Sinar matahari yang dibutuhkan untuk proses fotosintesis tidak terpenuhi. Selain itu, hampir semua tanaman contoh yang dipakai memiliki jumlah polong yang lebih banyak dibandingkan dengan tanaman lain sehingga proses pengisian biji tidak dapat terjadi secara optimal.

Pengaruh Aplikasi Kombinasi Insektisida Nabati dengan Cendawan L. lecanii terhadap Jumlah Polong Isi yang Terbentuk. Hasil penelitian menunjukkan bahwa jumlah polong isi terbanyak terjadi pada perlakuan kombinasi pestisida SBS $50 \mathrm{~g} / \mathrm{l}$ dengan cendawan L. lecanii, yaitu mencapai 36 buah/tanaman 
(Tabel 4). Sementara itu jumlah polong isi terendah terjadi pada perlakuan semua jenis pestisida nabati dengan dosis $75 \mathrm{~g} / \mathrm{ha}$ yang dikombinasikan dengan cendawan $L$. lecanii, yaitu hanya 29 buah/tanaman. Jumlah polong isi pada perlakuan tersebut sama dengan jumlah polong isi pada perlakuan tanpa aplikasi (29 buah/ tanaman). Peningkatan dosis pestisida nabati SDA tidak berpengaruh positif terhadap pembentukan polong isi, hal ini tampak dari jumlah polong isi yang semakin berkurang jika dosis dinaikkan. Berbeda dengan perlakuan peningkatan dosis pestisida SBS maupun SBJ, semakin tinggi dosis yang ditambahkan ke dalam formulasi dengan $L$. lecanii maka semakin efektif dalam mengendalikan telur kepik coklat. Hal ini tampak dari peningkatan jumlah polong isi yang terbentuk semakin banyak, namun hanya terbatas pada dosis $50 \mathrm{~g} / \mathrm{l}$ karena jika dosis dinaikkan justru polong isi yang terbentuk akan berkurang.

Jumlah polong isi pada tanaman kedelai merupakan salah satu indikator hasil total yang akan diperoleh setiap tanaman, namun demikian masih banyak parameter yang dapat digunakan sebagai tolok ukur dalam memprediksi hasil total yaitu jumlah luka tusukan pada tiap biji kedelai. Meski jumlah polong isi yang diperoleh lebih banyak akan tetapi bila biji-biji yang dihasilkan banyak yang luka karena tusukan stilet dari kepik coklat maka berat biji yang diperoleh juga rendah. Lebih dari itu, kualitas maupun kuantitas biji yang dihasilkan sangat jelek dan vigor tanaman jika akhirnya biji tersebut ditanam kembali sangat rendah.

\section{Pengaruh Kombinasi Aplikasi Insektisida Nabati dengan Cendawan $L$. lecanii terhadap Berat Biji.} Hasil penelitian menunjukkan bahwa semakin tinggi dosis pestisida nabati yang ditambahkan ke dalam suspensi cendawan entomopatogen semakin efektif dalam menekan penetasan telur sehingga jumlah nimfa maupun imago yang hidup juga terbatas. Akhirnya berat biji sebagai indikator keselamatan biji dari pengaruh kerusakan yang diakibatkan oleh kepik coklat berbeda nyata pada beberapa dosis insektisida nabati yang diaplikasikan. Namun demikian, dosis optimal untuk aplikasi insektisida nabati dicapai pada taraf $50 \mathrm{~g} / \mathrm{l} \mathrm{karena}$ jika dosis dinaikkan akan menurunkan berat biji yang ada. Kejadian ini berlaku pada semua perlakuan yang diuji, baik SDA, SBS maupun SBJ (Tabel 4). Berat biji tertinggi terjadi pada perlakuan kombinasi aplikasi SDA $50 \mathrm{~g} / \mathrm{l}$ dengan cendawan L. lecanii, yaitu 13,17 g/ tanaman oleh perlakuan SBJ $50 \mathrm{~g} / \mathrm{l}$ dengan $L$. lecanii yaitu $13,80 \mathrm{~g} / \mathrm{l}$. Kedua jenis insektisida nabati tersebut pada dosis $50 \mathrm{~g} / \mathrm{l}$ menunjukkan hasil lebih baik dalam melindungi biji dari serangan kepik coklat dibandingkan dengan perlakuan dosis 25 maupun $75 \mathrm{~g} / \mathrm{l}$ baik SDA, SBS mapun SBJ.

Hasil penelitian ini mengindikasikan bahwa insektisida nabati SDA, SBS maupun SBJ dosis $50 \mathrm{~g} / 1$ lebih baik dibandingkan dosis 25 maupun $75 \mathrm{~g} / \mathrm{l}$. Sementara itu, berat biji kedelai pada perlakuan kontrol (tanpa aplikasi) yaitu hanya 9,16 g/l. Diduga dosis $50 \mathrm{~g} / \mathrm{l}$ sudah optimal sehingga jika dinaikkan lagi dosisnya maka akan mengurangi efikasi dan bahkan kurang ekonomis. Hasil ini mendukung penelitian Sonkamble et al. (2000); Tripathy et al. (2001); Khalequzzaman \& Sultana (2006) bahwa dosis insektisida nabati dalam pengendalian hama tanaman tidak dianjurkan jika memakai bahan aktif yang melebihi 5\%. Hal ini berkaitan dengan penyediaan bahan dasar yang akan mengalami kesulitan di masa-masa mendatang dengan keterbatasan lahan yang tersedia.

\section{SIMPULAN}

Dari hasil penelitian ini dapat disimpulkan bahwa kombinasi insektisida nabati serbuk daun pacar cina Aglaia odorata, serbuk biji srikaya Annona squamosa, dan serbuk biji jarak Jatropha curcas dengan cendawan entomopatogen L. lecanii mampu meningkatkan efikasi pengendalian telur kepik coklat dibandingkan dengan aplikasi secara tunggal. Insektisida serbuk biji srikaya Annona squamosa maupun serbuk biji jarak Jatropha curcas yang dikombinasikan dengan $L$. lecanii lebih sinergis dibandingkan dengan kombinasi insektisida SDA dengan L. lecanii dalam mengendalikan telur kepik coklat. Dosis insektisida nabati $50 \mathrm{~g} / \mathrm{l}$ merupakan dosis yang tepat untuk dikombinasikan dengan $L$. lecanii dalam mengendalikan telur kepik coklat.

\section{DAFTAR PUSTAKA}

Abou-Arab AA \& Abu-Salem FM. 2010. Nutritional quality of Jatropha curcas seeds and effect of some physical and chemical treatments on their anti-nutritional factors. African J. of Food Sci. 4(3):93-103.

Adabie-Gomez DA, Monford KG, Agyir-Yawson A, Owusu-Biney \& Osae M. 2006. Evaluation of four local plant species for insecticidal activity against Sitophilus zeamais Mots (Coleoptera: Curculionidae) and Callosobruchus maculatus (F.) (Coleoptera: Bruchidae). Ghana J. Agric Sci. 39:147-154. 
Adebowale KO \& Adedire CD. 2006. Chemical composition and insecticidal properties of the underutilized Jatropha curcas seed oil. African J. of Biotechnol. 5(10):901-908.

Akbar E, Yaakob Z, Kamarudin SK, Ismail M \& Salimon J. 2009. Characteristics and composition of Jatropha curcas oil seed from Malaysia and its potential as biodiesel feedstock. European J. of Sci Res. 29(3):396-403.

Banapurmath NR, Tewari PG \& Hosmath RS. 2008. Performance and emmission characteristics of a DI compression ignition engine operated on Honge Jatropha and Sesame oil methyl esters. Renewable Energy 33:1982-1988.

Bandani AR \& Esmailpour N. 2006. Oil formulation of entomopathogenic fungus Beauveria bassiana against sunn pest Eurygaster integriceps Puton (Heteroptera: Scutelleridae). Commun Agric Appl Biol Sci. 71(2):443-448.

Chivandi E, Kachigunda B \& Fushal F. 2005. A comparison of the nutrient and antinutrient composition of industrilly prosessed Zimbabwean Jatropha curcas and Clycin max meal. Bak J. Biol Sci. 8:49-53.

Cliquet S \& Jackson MA. 2005. Impact of carbon and nitrogen nutrition on the quality yield and composition of blastospores of the bioinsecticidal fungus Paecilomyces fumosoroseus. J. of Industrial Microbiol and Biotechnol 32(5):204210.

Fatiha L, Huang Z, Ren SX \& Ali S. 2008. Effects of Verticillium lecanii on biological characteristics and life table bof Seragium japonicum (Coleoptera: Coccinellidae), a predator of whitflies under laboratory conditions. Insect Sci. 15(4):327-333.

Feng M, Chen GB \& Ying SH. 2004. Trials of Beauveria bassiana, Paecilomyces fumosoroseus and imidacloprid for management of Trialeurodes vaporariorum (Homoptera: Aleurodidae) on greenhouse grown lettuce. Biocontr Sci \& Technol. 14:531-544.

Ganga-Visalakshy PN, Krishnamoorthy A \& Kumar AM. 2005. Effects of plant oils and adhesive stickers on the mycelia growth and conidiation of Verticillium lecanii a potential entomopatogen. Phytopar. 33(4):367-369.
Gao L, Sun MH, Liu XZ \& Cha YS. 2007. Effect of carbon concentration and carbon to nitrogen ratio on the growth and sporulation of several biocontrol fungi. Mycol Res. 111(1):87-92.

Greger H, Pacher T, Brem B, Bacher M \& Hofer O. 2001. Insecticidal flavaglines and other compounds from Fijian Aglaia species. Phytochemist. 57:57-64.

Gunstone FD. 2004. Rapseed and Canola oil: Production, processing, properties and uses. London: Blackwell Publishing Ltd.

Inyang EN, McCartney HA, Oyejola B, Ibrahim L, Pye BJ, Archer SA \& Butt TM. 2000. Effect of formulation application and rain on the entomogenous fungus Metarhizium anisopliae on oil seed rape. Mycol Res. 104(6):653-661.

Ketaren S. 2005. Minyak dan asam lemak pangan. Penerbit Universitas Indonesia. Ed.I. 316 hlm.

Khalequzzaman M \& Sultana S. 2006. Insecticidal activity of Annona squamosa L. seed extracts against the red flour beetle Tribolium castaneum (Herbst). J. Bio Sci. 14:107-112.

Kimbonguila A, Nzikou JM, Matos L, Loumouamou B \& Ndangui CB. 2010. Proximate composition and physicochemical properties on the seeds and oil of Annona muricata grown in CongoBrazzaville. Res J. of Environ and Earth Sci 2(1):13-18.

Kim JS, Je YH \& Roh JY. 2010. Production of thermotolerant entomopatogonic Isaria fumosoroseus SFP-198 conidia in corn-corn oil mixture. Biol Contr. 45(3):404-409.

Koul O \& Walla S. 2009. Comparing impacts of plant extracts and pure allelochemicals and implications for pest control. CAB Reviews: Perspectives in Agriculture, Veterinary Sci, Nutrition and Natural Resources 4(049):1-30.

Kumar A \& Sharma S. 2008. An evaluation of multipurpose oil seed crop for industrial uses (Jatropha curcas): A review. Industrial Crops and Products. doi:10.1010/jandcrop.2008.01.001

Luthana YK. 2008. Minyak kelapa: Komposisi asam lemak. http://www. food\%20 entertaining.htm Diakses pada 28 Mar 2009. 
Magdi AO. 2007. Effect of different processing methods and nutrient composition, antinutritional factors and in-vivo protein digestability of Dolichos Lahab bean (Lablab purpuresus L. sweet). Pak J. Nutr 6:299-303.

Makkar HPS, Francis G \& Backer K. 2008. Protein concentrate from Jatropha curcas scewpressed seed cake and toxic and antinutritional factors in protein concentrate. J. Sci Food Agric. 88: 1542-1548.

Marti'nez-Herrera J, Siddhuraju P, Francis G, Da'vilaOrti'z G \& Becker K. 2006. Chemical composition, toxic/antimetabolic constituents, and effects of different treatments on their levels, in four provenances of Jatropha curcas L. from Mexico. Food Chem. 96:80-89.

Nehls U. 2008. Mastering ectomycorrhizal symbiosis: the impact of carbohydrates. J. of Experimental Botany 59(5):1097-1108.

Oladele PEO \& Oshodi AA. 2007. Nutritional potential of berlandier nettle spruge (Jatropha cathartica) seed. Pakistan J. of Nutrit. 6(4):345-348.

Prayogo Y. 2004. Keefektifan lima jenis cendawan entomopatogen terhadap hama pengisap polong kedelai Riptortus linearis (F.) (Hemiptera: Alydidae) dan dampaknya terhadap predator Oxyopes javanus Thorell (Araneida: Oxyopidae). [Tesis]. Bogor. Sekolah Pascasarjana. Institut Pertanian Bogor.

Prayogo Y. 2009a. Kajian cendawan entomopatogen Lecanicillium lecanii (Zimm.) (Viegas) Zare \& Gams untuk menekan perkembangan telur hama pengisap polong kedelai Riptortus linearis F. (Hemiptera: Alydidae). [Disertasi]. Departemen Proteksi Tanaman, Sekolah Pascasarjana, Institut Pertanian Bogor.

Prayogo Y. 2009b. Kompatibilitas Cendawan Entomopatogen Lecanicillium lecanii (Zare \& Gams) dengan Pestisida Nabati untuk Mengendalikan Telur Hama Pengisap Polong Kedelai Riptortus linearis (Hemiptera: Alydidae). Laporan Akhir Penelitian Ristek. [Tidak dipublikasi].

Proksch P, Edrada R, Ebel R, Bohnenstengel IF \& Nugroho BW. 2001. Chemistry and related compound in Aglaia species (Meliaceae). Curr Org Chem. 5:923-938.
Purwar JP \& Sachan GC. 2006. Synergistic effect of entomogenous fungi on some insecticides against Bihar hairy caterpillas Spilarctia obliqua (Lepidoptera: Arctiidae). Microbiol Res. 161(1):38-42.

Rangel DEN, Alston DG \& Roberts DW. 2008. Effects of physical and nutritional stress conditions during mycelial growth on conidial germination speed, adhesion to host cuticle and virulence of Metarhizium anisopliae an entomopathogenic fungus. Mycol Res. 112(11):1355-1361.

Safavi SA, Shah FA, Pakdel AK, Rosoulian GR, Bandani AR \& Butt TM. 2007. Effect of nutrition on growth and virulence of the entomopathogenic fungus Beauveria bassiana. FEMS Microbiol Lett. 270(1):116-123.

Sonkamble MM, Dhanorkar BK, Munde AT \& Sonkamble AM. 2000. Efficacy of indigenous plant extracts against Helicoverpa armigera (Hubner) and Spodoptera litura (Fabricius) under laboratory conditions. J. Soils Crops 10:236-239.

Sitch JC \& Jackson CW. 2008. Pre-penetration events effecting host specificity of Verticillium lecanii. Mycol Res. 101(5):535-541.

Su KJ, Skimer M \& Parker BL. 2010. Plant oils for improving thermotolerance of Beauveria bassiana. J. Microbiol Biotechnol. 20(9):13481350.

Sumartini, Prayogo Y, Wahyuni SI \& Hardaningsih S. 2001. Pemanfaatan jamur Metarhizium anisopliae untuk pengendalian pengisap polong Riptortus linearis pada kedelai. Simposium Pengendalian Hayati Serangga. Sukamandi, 1415 Maret 2001. $10 \mathrm{hlm}$.

Tripathy MK, Sahoo P, Das BC \& Mohanty S. 2001. Efficact of botanical oils plant powders and extracts against Callosobruchus chinensis Linn. attacking blackgram (Cv.T9). Legume Res. 24:8286.

Wang L, Huang J, You M, Guan X \& Liu B. 2007. Toxicity and feeding deterrence of crude toxin extracts of Lecanicillium (=Verticillium) lecanii (Hyphomycetes) against sweet potato whitfly Bemisia tabaci (Homoptera: Aleyrodidae). Pest Manag Sci. 63(4):381-387. 